\title{
Analisis In-Silico Struktur Tiga Dimensi Reseptor Trk A dan Trk B Protein Neurotrophin 3 Pada Gallus gallus (Chicken)
}

\author{
MUHAMMAD F. RAHMAN, AMIRUDDIN KASIM, MUCHLIS L. DJIRIMU, \\ I. MADE BUDIARSA* \\ Program Studi Pendidikan Biologi, PMIPA, Universitas Tadulako, Palu
}

Diterima: 17 Desember 2019 - Disetujui: 8 April 2020

(C) 2020 Jurusan Biologi FMIPA Universitas Cenderawasih

\begin{abstract}
NT3 protein is expressed by Neurotrophin 3 (NTF-3) which plays a role in the process of differentiation, survival of peripheral and neuropathological of neurons. The information of structure and function of NT-3 proteins is still very limited, especially in Gallus gallus. This study aims to predict the three-dimensional structure of the Trk A and Trk B proteins in Gallus gallus. The target protein obtained from the UniProt server with access codes Q91009 (Trk A) and Q91987 (Trk B) using the 6kzc 1.A (PDB ID) template was analyzed in silico through a homology approach and describing the structural assessment using Chimera UCSF software. The analysis showed that the Trk A protein had a QMEAN value of -0.08 , composed of 778 amino acids, mass 87334.30 Daltons, and Seq Identity $79.93 \%$. Trk B had a QMEAN value of 0.16 , consisting of 818 amino acids, mass 91732.05 Daltons, and Seq Identity $84.30 \%$.
\end{abstract}

Key words: NT3; homology; UCSF chimera; G. gallus

\section{PENDAHULUAN}

Neurotrophin-3 (NT3) merupakan protein yang berasal dari faktor neurotrofik yang memiliki peran penting (Chao, 2003) dalam diferensiasi, kelangsungan hidup neuron perifer dan neuropatologis sistem saraf (Maness et al., 1994; Nestler et al., 2009). Penelitian sebelumnya melaporkan bahwa kekurangan protein NT3 menyebabkan kerusakan sensorik atau kerusakan dalam menerima stimulus (Wilkinson et al., 1996) dan perkembangan ganglia yang bervariasi tergantung pada usia embrionik (Zhang et al., 1994).

Menurut Zhou \& Rush (1996) menjelaskan bahwa protein NT3 berperan sebagai ganglio-

* Alamat korespondensi:

PS. Pendidikan Biologi, PMIPA, Universitas Tadulako Jl. Soekarno-Hatta KM 9, Kota Palu, 94148, Indonesia. E-mail: budiarsa_imade@yahoo.com genesis, dapat mengikat reseptor tyrosine kinase (Trk) dalam menjalankan fungsi neurotrophin (Wilkinson et al., 1996).

Aktifasi neurotrophin bekerja pada beberapa reseptor, salah satunya adalah reseptor Trk (Ardiani et al., 2019). Reseptor Trk terdiri dari Trk A, Trk B dan Trk C memiliki afinitas berbeda dalam mengikat keluarga neurotrofin (Nestler et al., 2009), dan spesifik mengikat reseptor Trk C (Lamballe et al., 1991). Keunikan protein NT3 dalam mengikat reseptor Trk A dan Trk B memiliki afinitas rendah dibandingkan dengan Trk C (Julien et al., 2002), yang berperan dalam pensinyalan terhadap selektivitas, afinitas, dan fungsi protein (Hadad et al., 2017).

Informasi mengenai keunikan protein NT3 masih jarang dilaporkan terutama pada Gallus gallus, sehingga penting untuk dilakukan penelitian lebih lanjut dalam mengkaji sifat dan fungsi biokimia protein NT3. Perkembangan ilmu biologi memberikan dasar pengetahuan untuk mempelajari sifat dan fungsi protein melalui teknik komputasi 
Tabel 1. Parameter evaluasi model.

\begin{tabular}{cc}
\hline No & Parameter \\
\hline 1. & Seq Identity \\
2. & QMEAN \\
3. & GMQE \\
4. & Ramachandran Plot \\
\hline
\end{tabular}

(bioinformatika) yaitu dengan memprediksi struktur 3 dimensi yang dikembangkan untuk senyawa protein (Hillisch et al., 2004).

Mengkaji sifat dan fungsi protein dapat dilakukan melalui pendekatan homologi dengan analisis in-silico yang dilakukan menggunakan simulasi komputasi sebagai langkah untuk menyediakan informasi dalam memahami karakter, sifat dan interaksi protein ditingkat molekular (Wijaya \& Hasanah, 2016). Menurut Irfanuddin (2018) teknik komputasi telah berkembang pesat yang digunakan untuk menganalisis protein dan menyediakan berbagai solusi penyelesaian berupa data digital (Maisa, 2019). Bioinformatika belakangan ini menjadi salah satu cabang ilmu yang telah banyak digunakan sebagai alat analisis dan telah mampu mengkaji karakteristik gen serta mengungkap hubungan kekerabatan organisme pada tingkat inter dan intra spesies (Budiarsa et al., 2010).

\section{METODE PENELITIAN}

Penelitian dilakukan di Laboratorium Biologi PMIPA Universitas Tadulako menggunakan laptop dengan spesifikasi AMD E1-7010 APU 1,50 ghz RAM 4 GB terkoneksi jaringan internet untuk mengakses database sequence berupa file Protein Data Bank (PDB) yang divisualisasikan menggunakan software yang mendukung (Parikesit \& Anugroho, 2018).

Mengunduh protein target dalam format FASTA melalui situs UniProt (http://www.uniprotorg, serve), dan template 6kzc 1.A (PDB-ID) diperoleh dari hasil identifikasi template di SWISS-MODEL (http://swissmodel. expasy.org/) dengan identity tertinggi. Pemeriksaan kode akses protein dilakukan menggunakan situs Protein Data Bank (http://www.pdb.org/pdb/ home/homedo) untuk menentukan protein target dan visualisasi karakteristik struktur dianalisis menggunakan software University of California at San Fransisco (UCSF) Chimera serta komposisi

\begin{tabular}{|c|c|c|c|c|c|c|c|}
\hline$\square$ & P35739 & NTRK1_RAT & 点 & $\begin{array}{l}\text { High affinity nerve growth } \\
\text { factor } r . .\end{array}$ & Ntrk1 Trk, Trka & Rattus norvegicus (Rat) & 799 \\
\hline$\square$ & Q3UFB7 & NTRK1_MOUSE & 点 & $\begin{array}{l}\text { High affinity nerve growth } \\
\text { factor } r \text {. }\end{array}$ & Ntrk1 & Mus musculus (Mouse) & 799 \\
\hline$\square$ & Q91009 & NTRK1_CHICK & 害 & $\begin{array}{l}\text { High affinity nerve growth } \\
\text { factor } r . .\end{array}$ & NTRK1 TRKA & Gallus gallus (Chicken) & 778 \\
\hline$\square$ & Q03351 & NTRK3_RAT & 部 & NT-3 growth factor receptor & Ntrk3 TrkC & Rattus norvegicus (Rat) & 864 \\
\hline$\square$ & Q16620 & NTRK2_HUMAN & 窖 & $\begin{array}{l}\text { BDNF/NT-3 growth factors } \\
\text { receptor }\end{array}$ & NTRK2 TRKB & Homo sapiens (Human) & 822 \\
\hline$\square$ & Q16288 & NTRK3_HUMAN & 祭 & NT-3 growth factor receptor & NTRK3 TRKC & Homo sapiens (Human) & 839 \\
\hline$\square$ & Q6VNS1 & NTRK3_MOUSE & 牙 & NT-3 growth factor receptor & Ntrk3 TrkC & Mus musculus (Mouse) & 825 \\
\hline$\square$ & P15209 & NTRK2_MOUSE & 空 & $\begin{array}{l}\text { BDNF/NT-3 growth factors } \\
\text { receptor }\end{array}$ & Ntrk2 Trkb & Mus musculus (Mouse) & 821 \\
\hline$\square$ & Q91044 & NTRK3_CHICK & 整 & NT-3 growth factor receptor & NTRK3 TRKC & Gallus gallus (Chicken) & 827 \\
\hline$\square$ & P24786 & NTRK3_PIG & 존 & TNT growth factor Teceptor & 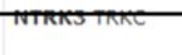 & 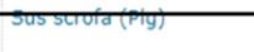 & हैग \\
\hline$\square$ & Q63604 & NTRK2_RAT & 蛋 & $\begin{array}{l}\text { BDNF/NT-3 growth factors } \\
\text { receptor }\end{array}$ & Ntrk2 Trkb & Rattus norvegicus (Rat) & 821 \\
\hline$\square$ & Q91987 & NTRK2_CHICK & 整 & $\begin{array}{l}\text { BDNF/NT-3 growth factors } \\
\text { receptor }\end{array}$ & NTRK2 TRKB & Gallus gallus (Chicken) & 818 \\
\hline$\square$ & P62993 & GRB2_HUMAN L & 족 & $\begin{array}{l}\text { Growth factor Teceptor-boumt } \\
\text { protei... }\end{array}$ & बाराटर मजा & 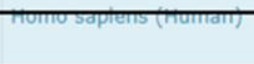 & \\
\hline
\end{tabular}

Gambar 1. Pencarian sekuen protein target Trk A kode akses “Q91009" dan Trk B kode akses "Q91987". 

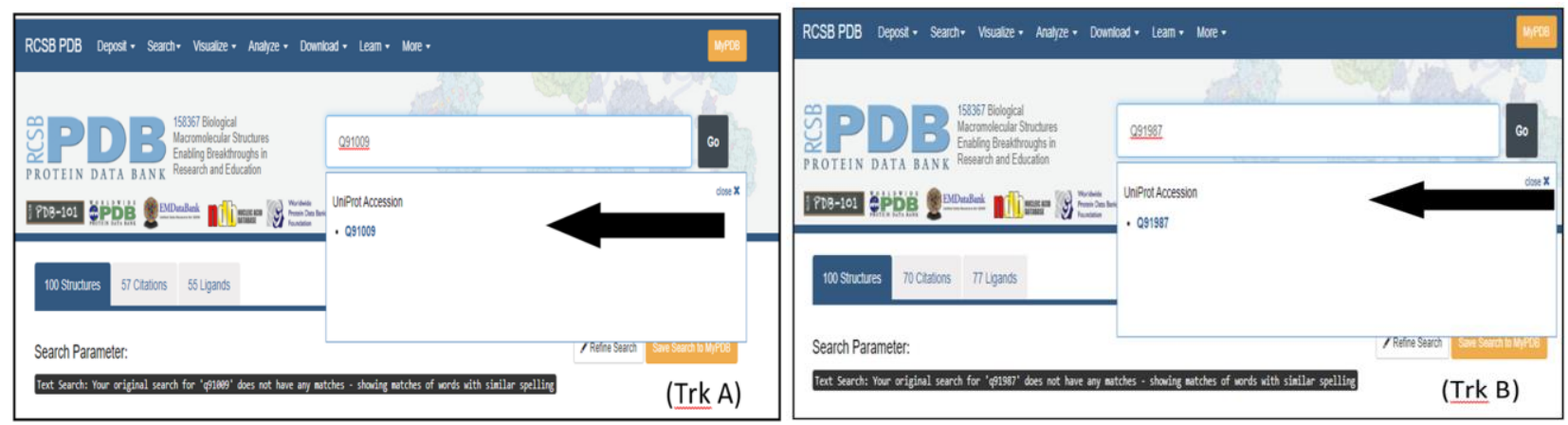

Gambar 2. Hasil penelusuran protein Trk A dan Trk B pada PDB.
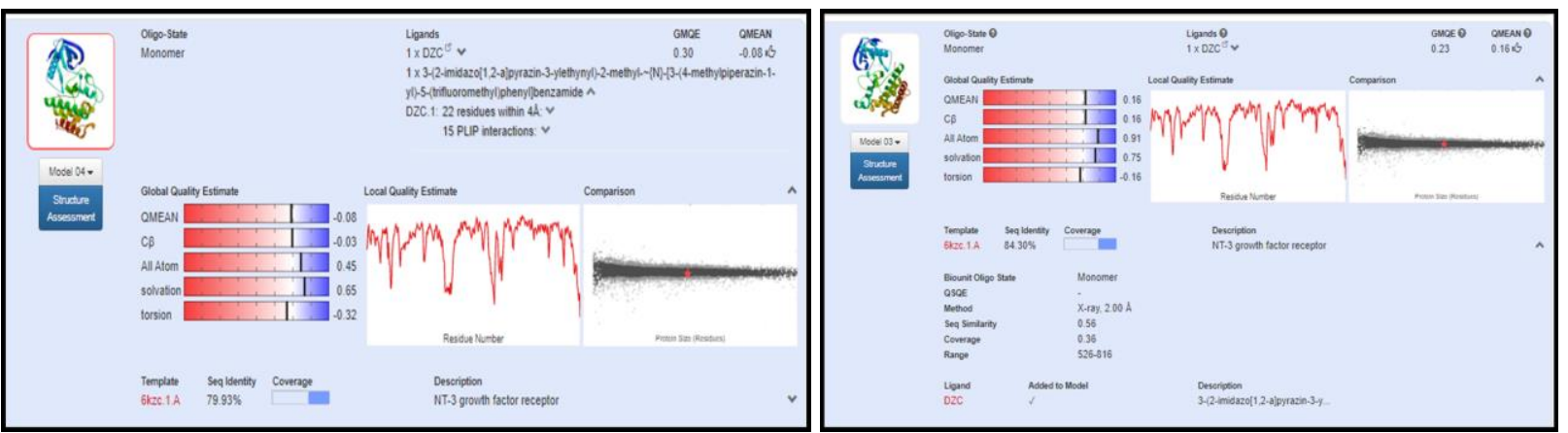

Gambar 3. Struktur tiga dimensi Protein TrK A, dan Protein Trk B.
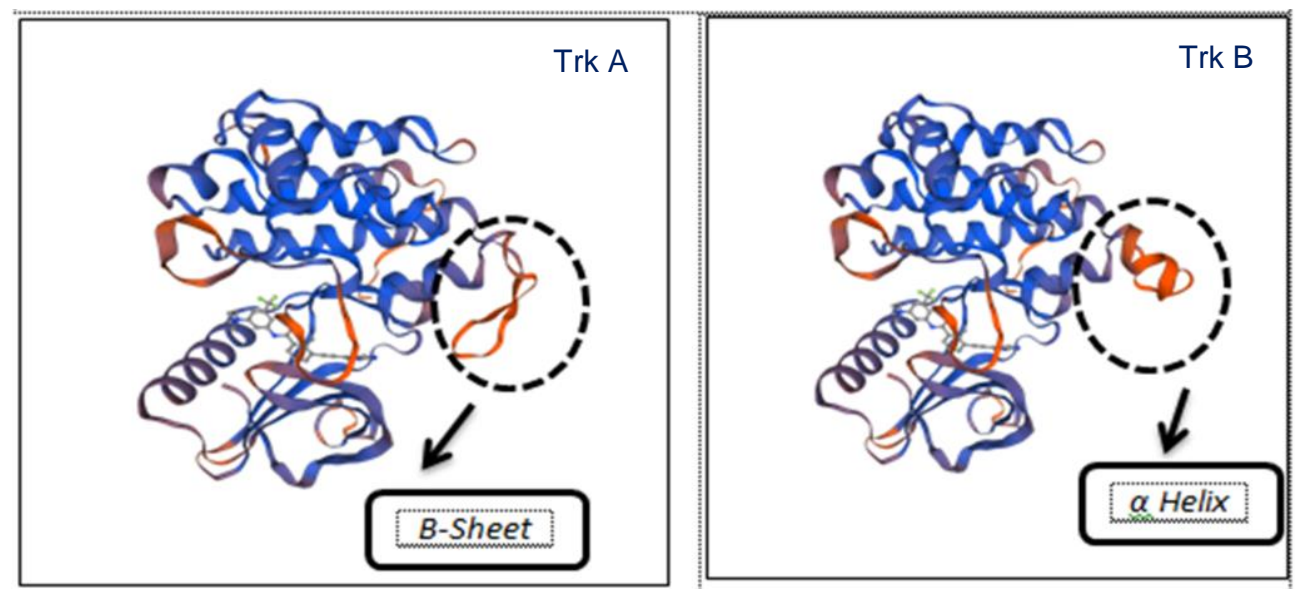

Gambar 4. Perbandingan model Trk A dan Trk B.

asam amino diperoleh menggunakan Bioedit versi 7.2.5.

\section{Penentuan Protein Target}

Penentuan protein target dilakukan menggunakan server Protein Data Bank (PDB) (https://www.rcsb.org), protein dipilih berdasarkan kode akses tertentu dalam situs uniprot yang belum terdaftar di server PDB. Protein target adalah protein yang belum ditentukan struktur tiga dimensi proteinnya secara eksperimen (Berman et al., 2006).

\section{Pemodelan Struktur Tiga Dimensi Protein Target}

Pemodelan protein target dianalisis secara insilico yang dapat menyediakan informasi dalam 
memahami karakter, sifat dan interaksi protein ditingkat molekular (Wijaya \& Hasanah, 2016). Pemodelan dilakukan melalui pendekatan homologi menggunakan SWISS MODEL. Memasukkan sequence protein target pada upload target sequence file kemudian memilih build model untuk mendapatkan hasil prediksi protein target. Hasil pemodelan dilakukan dengan memilih template yang memiliki nilai identity tertinggi. Amelia \& Iryani (2012) mengemukakan bahwa template dengan identity tertinggi akan mengurangi kesalahan dalam memprediksi struktur tiga dimensi protein target.

\section{Visualisasi menggunakan UCSF Chimera}

Penilaian struktur tiga dimensi protein target dilakukan menggunakan software UCSF Chimera di askes secara offline. Tujuannya adalah untuk menampilkan daerah ikatan hydrogen dan residu asam amino hidrofobik sebagai penentu daerah residu amino pada ikatan peptida yang terlibat dalam menentukan kestabilan protein (Malau \& Sianturi, 2019).

\section{HASIL DAN PEMBAHASAN}

\section{Protein Target}

Penggandaan gen menghasilkan turunan sifat yang sama dengan induknya ketika gen itu diekspresikan menjadi sebuah protein fungsional (Mawardi \& Simonapendi, 2016). Reseptor Trk A dan Trk B merupakan protein fungsional yang berfungsi dalam diferensiasi dan kelangsungan hidup sistem saraf.

Protein target ditentukan berdasarkan hasil pemeriksaan kode akses protein yang diperoleh dari database UniProt (Gambar 1). Kode akses protein target belum terdaftar dalam situs PDB menunjukkan bahwa struktur tiga dimensi protein tersebut belum diprediksi secara eksperimen, sehingga perlu dilakukan kajian struktur tiga dimensi protein secara in-silico (Gambar 2). Pada penelitian ini protein yang akan diprediksi struktur 3 dimensi adalah protein Trk A dan Trk $\mathrm{B}$, dengan kode akses masing-masing Q91009 (UniProt ID) dan Q91987 (UniProt ID).

\section{Struktur Tiga Dimensi Protein Target}

Struktur tiga dimensi protein Trk A dan Trk B dibangun pada server SWISS MODEL dengan template 6kzc.1.A yang ditunjukkan pada Gambar 3.

Hasil prediksi struktur tiga dimensi protein TrK A dengan template memiliki identity sebesar 79,93 \%, Quality Model Energy Analysis (QMEAN) -0,08 dan Global Model Quality Estimation (GMQE) 0,30. Trk B memiliki identity 84,30\%, QMEAN 0,16 , dan GMQE 0,23. Struktur tiga dimensi memiliki nilai identity tinggi antara target dan template yang menunjukkan model tergolong baik. Baker \& Sali (2001) menjelaskan bahwa pemilihan template dengan nilai identity tertinggi akan membantu mengurangi kesalahan dalam memprediksi struktur tiga dimensi. Nilai QMEAN menjadi parameter kualitas baik buruknya model yang menggabungkan beberapa fungsi penilaian untuk memperkirakan kualitas model, semakin bagus model ditandai dengan ibu jari yang menghadap ke atas. Nilai GMQE dari 0-1 menandakan kecocokan antara target dan template yang mencerminkan akurasi model yang dibangun (Rekik et al., 2015).

Struktur model yang terbangun memiliki perbedaan yakni Trk A berbentuk B-Sheet dengan residu asam amino Asp 590 A, Ala 591 A, Lys 592 A, Ile 593 A, Leu 594 A, Asp 595 A, Gln 596 A, Gly 597 A, Gln 598 A, Gly 599 A, Gln 600 A, Pro 601 A, Cys 602 A, Gly 603 A dan Gln 604 A sedangkan Trk B berbentuk a Helix dengan residu asam amino Pro 630 A, Asp 631 A, Ala 632 A, Val 633 A, Leu 634 A, Met, 635 A, Ala 636 A, Glu 637 A, Gly 638 A, Asn 639 A, Arg 640 A, Pro 641 A, Ala 642 A, dan Glu 643 A (Gambar 4).

\section{Ramachandran Plot}

Plot ramachandran atau plot sebaran 2D yang memiliki perbandingan pasangan backbone torsion angel $\mathrm{p}$ (phi) dan $\Psi$ (psi) dalam memprediksi sebaran asam amino sebagai indikator kualitas intrinsik pada struktur 3 dimensi (Lukitaningsih et al., 2013) dan menggambarkan kelayakan struktur tiga dimensi pada model yang dibangun. Plot ramachandran terbagi atas kuadran I, II, III dan IV terdiri dari most favoured regions, additional allowed 
regions, generously allowed regions dan disallowed regions (Gambar 5).

Hasil Plot ramachandran Trk A posisi most favoured regions 91,5\%, additional allowed regions $7,4 \%$, generously allowed regions $1,2 \%$ sementara disallowed regions $0,0 \%$, dan Trk B most favoured regions 92,7\%, additional allowed regions 6,2\%, generously allowed regions $1,2 \%$, dan disallowed regions $0,0 \%$. Hal ini menunjukkan kualitas model semakin baik dan stabil karena sebaran asam amino pada most favoured regions lebih tinggi dibanding pada disallowed regions. Menurut Bosco
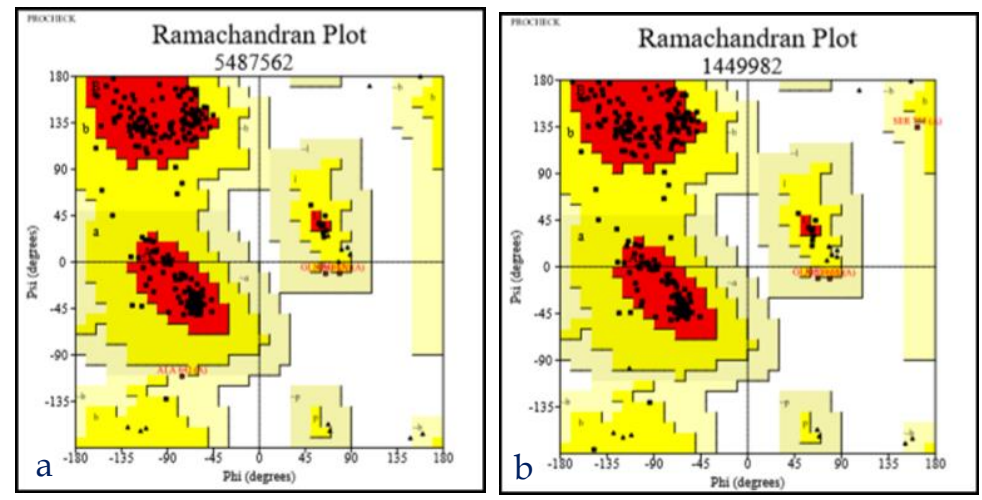

Gambar 5. Plot Ramachandran Trk A (a), dan b. Trk B (b).
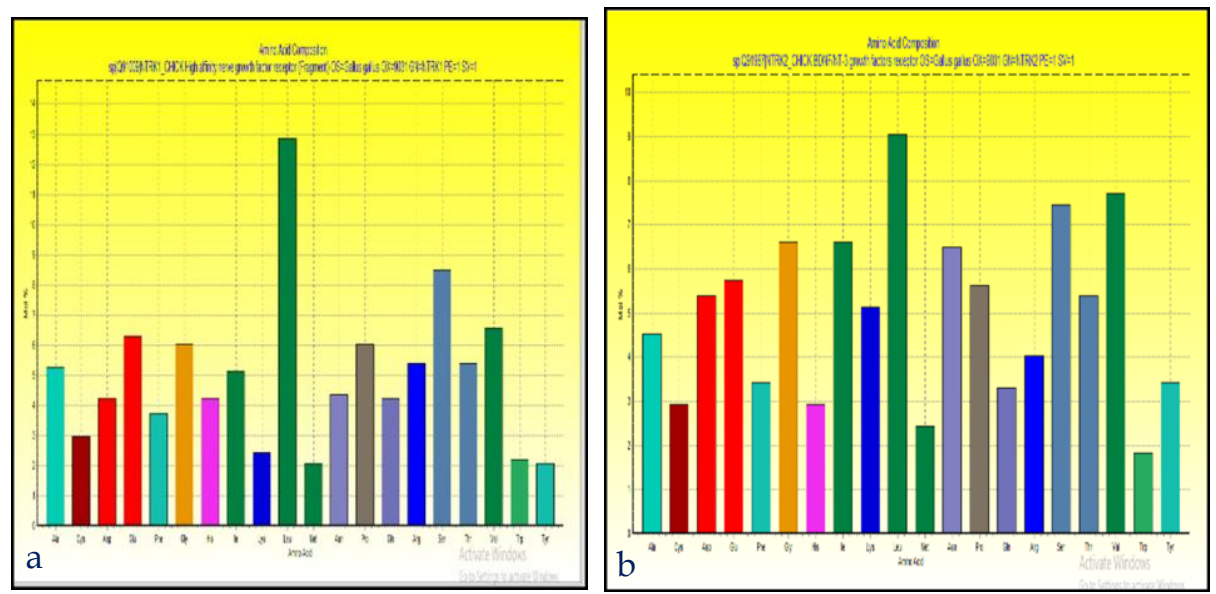

Gambar 6. Diagram Komposisi Asam Amino Protein Trk A (a) dan Trk B (b).
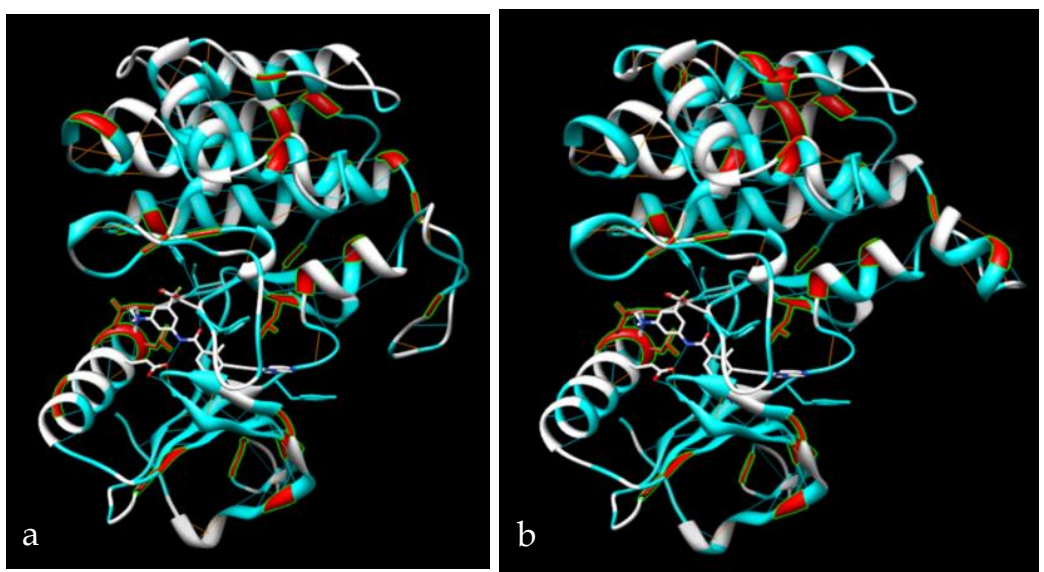

Gambar 7. Hasil pencarian daerah hydrophobic (warna biru), asam amino leusin (Leu) (warna merah) dan ikatan hydrogen ditampilkan berupa garis berwarna. 
\& Brasseur (2005) memaparkan bahwa semakin besar nilai pada most favoured regions menandakan kualitas model tersebut semakin baik dan stabil. Apabila residu non glisin pada daerah disallowed region lebih kecil dari 15\% maka kualitas struktur protein dikatakan baik (Lovell et al., 2003; Gowder et al., 2014).

\section{Komposisi Asam Amino Protein Target}

Hasil analisis komposisi asam amino dari kedua protein Trk A dan Trk B. Trk A memiliki persentase asam amino terendah ialah Met: 2,06 \% dan Tyr: 2,06\%. Persentase asam amino pada Trk B terendah ialah Met : 2,44\% dan Trp : 1,83\%, dapat dilihat pada Gambar 6. Asam amino dari protein Trk A dan Trk B memiliki kesamaan masing-masing memiliki persentase asam amino Leusin (Leu) yang tinggi sebesar $12,85 \%$ dan 9,05\%. Hasil penelitian ini didukung oleh penelitian Windish et al. (1995) yang melaporkan bahwa reseptor Trk A dan Trk B kaya akan asam amino leusin dengan mendominasi daerah hidrofobik atau tergolong dalam asam amino non polar yang sulit berinteraksi dengan air.

\section{Visualisasi mengunakan UCSF Chimera}

Hasil visualisasi struktur tiga dimensi protein Trk A dan Trk B memiliki daerah hidrofobik dengan residu asam amino Leu, Val, Thr, Phe, Ala, His, Lys, Met, Gly, Trp, Ile dan Cys (Gambar 7). Menurut Gowder (2014), pada daerah hidrofobik merupakan faktor yang mengatur pelipatan dan stabilitas protein pada lingkungan yang disukai baik di interior protein. Hal tersebut mendukung protein dalam mempertahankan struktur tiga dimensi serta menghasilkan protein yang aktif. Protein Trk A dan Trk B memiliki 292 ikatan hidrogen. Sheu et al., (2009) menjelaskan bahwa ikatan hidrogen merupakan salah satu ikatan protein yang berfungsi dalam menstabilkan rangkaian residu asam amino pada struktur tiga dimensi protein. Selain itu, ikatan hydrogen merupakan elemen kunci yang menentukan dinamika stabilitas protein.

\section{KESIMPULAN}

Hasil penelitian menunjukkan bahwa protein Trk A memiliki nilai QMEAN -0,08, tersusun dari 778 asam amino, massa 87334,30 Daltons dan identity 79,93 \%. Trk B memiliki nilai QMEAN 0,16, tersusun dari 818 asam amino, massa 91732,05 Daltons dan identity 84,30 \%. Informasi yang diperoleh dari penelitian dapat memberikan referensi baru mengenai struktur tiga dimensi protein Trk A dan Trk B di tingkat molekular untuk penelitian lebih lanjut.

\section{DAFTAR PUSTAKA}

Amelia, F. dan Iryani. 2012. Comparrative modelling protein vaksin NA BTB H5N1 menggunakan SWISS MODEL. Jurnal Sains dan Teknologi. 4(2): 165-169.

Ardiani, Y., Defrin, dan H. Yetti. 2019. Kajian pustaka: Kadar brain derived neurotrophic factor mempengaruhi berat badan lahir pada bayi. Jurnal Ilmiah Universitas Batanghari Jambi. 19(1): 152-155.

Baker, D., and A. Sali. 2001. Protein structure prediction and structural genomics. Science. 294:93-96.

Berman, H., K. Henrick, H. Nakamura, and J.L. Markley. 2006. The orldwide Protein Data Bank (wwPDB): ensuring a single, uniform archive of PDB data. Nucleic Acids Research. 35: 301-303.

Bosco, K.H., and R. Brasseur. 2005. The ramachandran plots of glycine and pre-proline. BMC Structural Biology. 5(14): 111.

Budiarsa, I. M., I.W.T. Artama, L. Sembiring, and J. Situmorang. 2010. Analisis filogenetik burung maleo (Macrocephalon maleo) berdasarkan sekuen intron satu gen rhodopsin (RDP1) nukleus. Biota. 15(2): 160-166.

Chao, M.V. 2003. Neurotrophins and their receptors: a convergence point for many signalling pathways. Neuroscience. 4: 299-309.

Gowder, S.M., J. Chatterjee, T. Chaudhuri, and K. Paul. 2014. Prediction and analysis of surface hydrophobic residue in tertiary structure of protein. The Scientific World Journal. Article ID 971258.1-7.

Haddad, Y., V. Adam, and Z. Heger. 2017. Trk receptors and neurotrophin cross-interactions: new perspectives toward manipulating therapeutic side-effects. Frontiers in Molecular Neuroscience. 10: 1-7.

Hillisch, A., L.F. Pineda and R. Hilgenfeld. 2004. Utility of homology models in the drug discovery process. Drug Discovery Today. 171(2): 659-669.

Irfanuddin. 2018. Karakteristik biomolekuler mutasi amyloid precursor protein sebagai penyebab penyakit alzheimer yang dianalisis melalui media bioinformatika. Sriwijaya Journal of Medicine. 1(1): 61-73. 
Jullien, J., V. Guili., L.F. Reichardt, and B.B. Rudkin. 2002. Molecular kinetics of nerve growth factor receptor trafficking and activation. The Journal of Biological Chemistry. 277(41): 38.700-38.708.

Lamballe, F., R. Klein, and M. Barbacid. 1991. Trk c, a new member of the trk family of tyrosine protein kinases, is a receptor for neurotrophin-3. Depertement of Moleculer Biology Bristol-Myers Squibb Pharmaceutical research Institute Princeton. 66: 967-979.

Lukitaningsih, E., A.A. Mustikawaty, and A. Sudarmanto. 2013. Homology modelling dan moleculer docking senyawa aktif dari bengkoang (Pachyrrhizus erosus) sebagai inhibitor tirosinase pada Homo sapiens. Jurnal Ilmu Kefarmasisan Indonesia. 11(2): 134-141.

Lovell, S.C., I.W. Davis, W.B. Arendall Ill, P.I.W. De Bakker, J.M. Word, M.G. Prisant, J.S. Richardson, and D.C. Richardson. 2003. Structure validation by calpha geometry: phi, psi and c beta deviation. Proteins: Structure, Function \& Genetics. 50: 437-450.

Malau, N.D., and M. Sianturi. 2019. Analisa interaksi hidrofobik terhadap kestabilan termal enzim xilanase Aspergillus niger. Jurnal Edu Mat Sains. 3(2): 215-227.

Maisa, B. 2019. Penggunaan workflows dalam aplikasi bioinformatika geneious untuk menganalisis data genomik. Jurnal Kesehatan Andalas. 8 (Supplement 1): 4750.

Maness, L.M., A.J Kastin., J.T Weber., W.A Banks., B.S Beckman, and J.E. Zadina. 1994. The neurotrophins and their receptors : structure, function, and neuropathology. Nenroscience and Biobehavioral Reviews. 18(1): 143-159.

Mawardi, A., and M.L. Simonapendi. 2016. Uji efektivitas metode isolasi DNA genom kopi arabika (Coffea arabica L.) asal kabupaten Jayawijaya. Jurnal Biologi Papua. 8(1): 7-12.

Nestler, E.J., S.E. Hyman, and R.C. Malenka. 2009. Molecular neuropharmacology: a foundation for clinical neuroscience $2^{\text {nd }}$ edition. USA: McGraw-Hill.
Parikesit, A.A., and D. Anugrogo. 2018. Kajian prediksi 3dimensi biomarker kanker payudara dari jalur ekspresi LINCRA-ROR/mir-145/ARF6. Jurnal Sains dan Teknologi. 2(1): 10-19.

Rekik, I., Z. Chaabenel, C. Douglas Grubb, N. Drira1, F. Cheour, and A. Elleuch. 2015. In silico characterization and molecular modeling of double-strand break repair protein MRE11 from Phoenix dactylifera $\mathrm{v}$ deglet nour. Theoretical Biology and Medical Modelling. 12: 23. doi: 10.1186/s12976-015-0013-2.

Sheu, S., E.W. Schlag, L. Heinrich, Selzle, and D.Y. Yang. 2009. Hydrogen bonds in membrane proteins. J. Phys. Chem. 113: 5318-5326.

Wijaya, H., dan F. Hasanah. 2016. Prediksi struktur tiga dimensi protein alergen pangan dengan metode homologi menggunakan program SWISS MODEL. Bioporpal Industri. 7(2): 83-94.

Wilkinson, G.A., I. Farinas., C. Backus, C.K. Yoshida, and L.F. Reichardt. 1996. Neurotrophin-3 is a survival factor in vivo for early mouse trigeminal neurons. The Journal of Neuroscience. 16(23): 7661-7669.

Windisch, J.M., R. Marksteiner, M.E. Lang, B. Auer, and R. Schneider. 1995. Brain-derived neurotrophic factor, neurotrophin-3 and neurotrophin- 4 bind to a single leucine-rich motif of Trk B. Biochemistry. (34): 1125611263.

Zhang, D., L. Yao, and P. Bernd. 1994. Expression of Trk and neurotrophin mRNA in dorsal root and sympathetic ganglia of the quail during development. Journal of Neurobiology. 25(12): 1517-1532.

Zhou, X.F., and R.A. Rush. 1996. Funcional Roles of Neurotrophin3 in the Developing and Mature Sympathetic Nervous System. Moleculer Neurobiology. 133(3): 185-197. 